\title{
The development of healthcare mobile robot for helping medical personnel in dealing with COVID-19 patients
}

\author{
Nova Eka Budiyanta ${ }^{1}$, Linda Wijayanti ${ }^{2}$, Widodo Widjaja Basuki ${ }^{3}$, \\ Harlianto Tanudjaja ${ }^{4}$, V. Budi Kartadinata ${ }^{5}$ \\ ${ }^{1,2,5}$ Department of Electrical Engineering, Universitas Katolik Indonesia Atma Jaya, Indonesia \\ ${ }^{3}$ Department of Mechanical Engineering, Universitas Katolik Indonesia Atma Jaya, Indonesia \\ ${ }^{4}$ Department of Information System, Universitas Katolik Indonesia Atma Jaya, Indonesia
}

\section{Article Info}

Article history:

Received Sep 23, 2020

Revised Mar 31, 2021

Accepted Apr 2, 2021

\section{Keywords:}

COVID-19

Healthcare mobile robot

Medical assistant

Robot development

Wireless robot

\begin{abstract}
Coronavirus disease (COVID-19) pandemic has succeeded in shaking the whole world. This situation requires medical personnel to work extraordinarily to treat COVID-19 patients with very high risk of transmission. For this reason, this study aimed to helping medical personnel handle COVID-19 patients through robotic technology. The development method in this study is proposed as a way to develop robots to serve patients in isolation rooms controlled at a distance away from other rooms. From technical testing, the movement of the robot with a load of $12.59 \mathrm{~kg}$ only experienced a speed slowdown which was not too significant, namely at $0.43 \mathrm{~s}$ with an average percentage of slowdown of $8.96 \%$. The accuracy of the proximity sensor testing is close to perfect with an accuracy percentage of $99.62 \%$. The robot control distance was monitored and running well. Also, the increase in motor temperature is not too large, supported by measurement results of $32.13 \%$. From non-technical testing, based on the test results of the feasibility test of all respondents with 25 indicators reached a feasibility level of $91.46 \%$. In other words, healthcare mobile robots developed for helping medical personnel in dealing with COVID-19 patients are very feasible to be applied in hospitals.
\end{abstract}

This is an open access article under the CC BY-SA license.

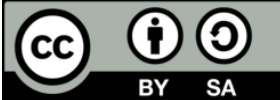

\section{Corresponding Author:}

Nova Eka Budiyanta

Department of Electrical Engineering

Universitas Katolik Indonesia Atma Jaya

$3^{\text {th }}$ Campus BSD, Raya Cisauk Lapan St., Sampora, Kec. Cisauk, Tangerang, Banten 15345, Indonesia

Email: nova.eka@atmajaya.ac.id

\section{INTRODUCTION}

The Coronavirus disease (COVID-19) pandemic which was declared by the World Health Organization (WHO) on January 30, 2020 [1] has had a tremendous impact on every nation in the last few months, including Indonesia. A month since the announcement of the first case of Coronavirus disease, known as COVID-19 in Indonesia, there has been a significant increase, reaching around 2000 people infected with the virus throughout Indonesia, and around 50\% in the Special Capital District of Jakarta (DKI Jakarta) Province. This number is likely to increase because the number of positive patients with COVID-19 is currently still increasing. This is very concerning because medical personnel and health workers are needed to treat patients during the COVID-19 pandemic that has occurred around the world.

COVID-19 patients who experience mild and moderate symptoms who are hospitalized must enter isolation rooms. Quite a number of patients with the condition are still able to carry out their normal activities. They must be monitored by doctors and nurses for several days until the COVID-19 test negative 
results are declared healthy and can go home. The treatment of COVID-19 patients in hospitals requires frequent contact of doctors and nurses with patients in terms of patient visits and consultations with doctors, measurements of body temperature, blood pressure and heart rate of patients carried out by nurses, delivering medicines by nurses, delivering food and drinks and other equipment by nutrition officers. With frequent direct contact with patients, the chances of being infected are higher. Also, with the limitations of personal protective equipment (PPE) and to reduce the interaction of medical personnel and health workers with patients, a facility is needed that can be used to serve patients without the need for direct contact, so as to reduce exposure to the COVID-19 virus.

Based on this problem, a tool that can be controlled by the operator is needed to replace doctors and nurses coming to the patient so that direct contact with the patient can be reduced. Increases in the application of automation and medical robotics occur every day [2]-[5]. There are several previous studies regarding healthcare robotics. As implemented in the Polyclinic of Modena (Italy) [6], Humanoid companion robot for patients [7], assistive robot [8]-[11], end-effector wheeled robotic arm [12], automation and control system in medical sector [13]-[15], and also a robot with a rehabilitation function and motion assitance [16]-[23]. In addition, there are also robots with slightly different goals, namely to disinfect the environment using UV light which can also be applied for healthcare purposes [24].

From some of the results that have been described, the main function needed in designing this tool is the accuracy in every movement, such as in a multi degree of freedom (DOF) surgical robot which requires a minimum error in every movement [25]-[27]. Communication is used so that doctors and nurses can interact directly with patients remotely. Then, to help provide for the patient's needs, a device that can be controlled remotely is needed to serve the patient's needs such as food, drink and medicine. From some of the known needs, it is concluded that this development is a robot that can be controlled remotely to help doctors and nurses interact and serve the needs of patients in isolation rooms.

\section{RESEARCH METHOD}

\subsection{Development model}

The application of supporting tools for handling COVID-19 patients has received special attention from researchers around the world. The approach taken in this study adopts the Pressman Development model. One of the development models by Pressman is the waterfall model or often referred to as a linear sequential model [28]. Pressman argues that the waterfall development model contains an approach that can be used to support sequential and systematic development. The waterfall model has 4 stages, namely Analysis as a process of gathering needs, design to translate requirements into quality hardware and software representations before development begins, development as a means of implementing design to be translated into hardware and software, and Tests to test the functions and benefits of product development. The waterfall model can be viewed from the flow chart in Figure 1.

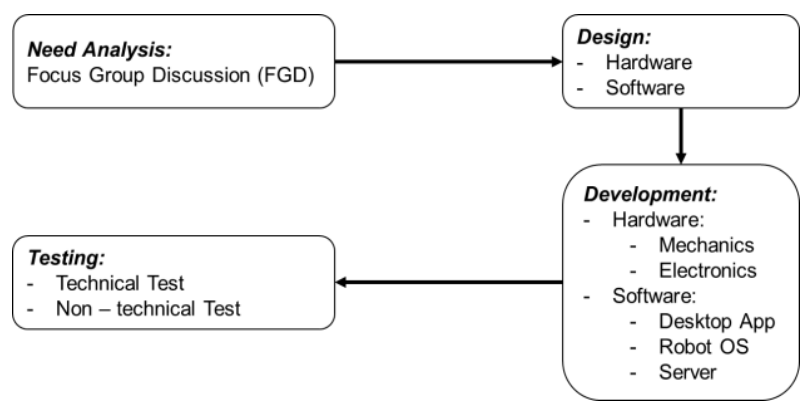

Figure 1. Development model adopted from waterfall model by pressman [28]

Based on Figure 1, the most important thing to do to start this research is need analysis. Identification of needs is carried out in order to identify real needs and problems that occur in the field to be resolved. In this stage, information is collected to create a robot development flow. Information gathering was carried out by means of a focus group discussion (FGD). The FGD was carried out by discussing with the user, in this case the hospital health worker, to find out the functional requirements of the robot being made.

After the needs have been obtained, then the design is carried out to map the technical aspects of hardware and software. Hardware design is carried out more on mapping the power supply requirements, electronic circuits, control systems, and other required peripherals. As for the software, it is done more on mapping the needs of the user interface, networking, and operating system for robots. 
Furthermore, after the hardware and software design is determined, the robot manufacturing process is carried out. The robot working process is divided into hardware and software work. Hardware work is done by making a printed circuit board (PCB) board consisting of 2 boards, namely the power supply board and the control board. Then the software work is done by creating a microcontroller program code on the control board and, making desktop software, and also making a server for internal video conferencing without using the internet.

After the robot manufacturing stage is carried out, then the testing phase is carried out on the robot. Testing on the technical aspects is carried out on the speed test with and without load, the distance measurement test on the 3 sides of the robot (front, right, left), control distance testing, and motor performance testing. Testing on non-technical aspects is carried out by means of a feasibility test. The feasibility test was carried out with a descriptive statistical approach. The purpose of this test is to determine the feasibility of the robot made for implementation in the field. Quantitative data is in the form of calculated and/or measurement results and can be processed by adding it up and then comparing it with the expected number so that a percentage is obtained. The percentage is determined by the following calculation:

$$
\text { Percentage }(\%)=\frac{\text { Total Actual Score }}{\text { TOtal Ideal Score }} \times 100 \%
$$

Analysis of numerical data in this activity uses a likert scale, because the likert scale is more reliable when compared to the single-team scale [29]. After the percentage measurement scale is formed then the data is grouped according to the percentage achieved and interpreted into the score conversion table as in Table 1.

Table 1. Score conversion

\begin{tabular}{cc}
\hline Percentage $(\%)$ & Criterias \\
\hline $100-76$ & Very Feasible \\
$75-51$ & Feasible \\
$50-26$ & Not Feasible \\
$25-0$ & Very Infeasible \\
\hline
\end{tabular}

\subsection{Hardware}

Good hardware is very influential on the running of the robot. There are several blocks of important components used in making this robot hardware. The component blocks implemented in the manufacture of this robot include connection blocks, sensor blocks and liquid crystal display (LCD) indicators, main motor driver blocks, stepper blocks and main switch connections, charger blocks, and safety blocks. Power supply used 2 batteries with 12v 20Ah capacity arranged in series. The power supply is used to supply power to all electronic hardware systems.

Robots are supported by connectivity between sensor, microcontrollers, microcontroller controls, tablets, and robot cameras with a personal computer (PC) or Laptop in the control room. There are 2 ethernet shields and an IP camera connected to the access point. The function of the ethernet shield is as an intermediary for sending and receiving data to and from the microcontroller. The robot system block diagram can be seen in Figure 2.

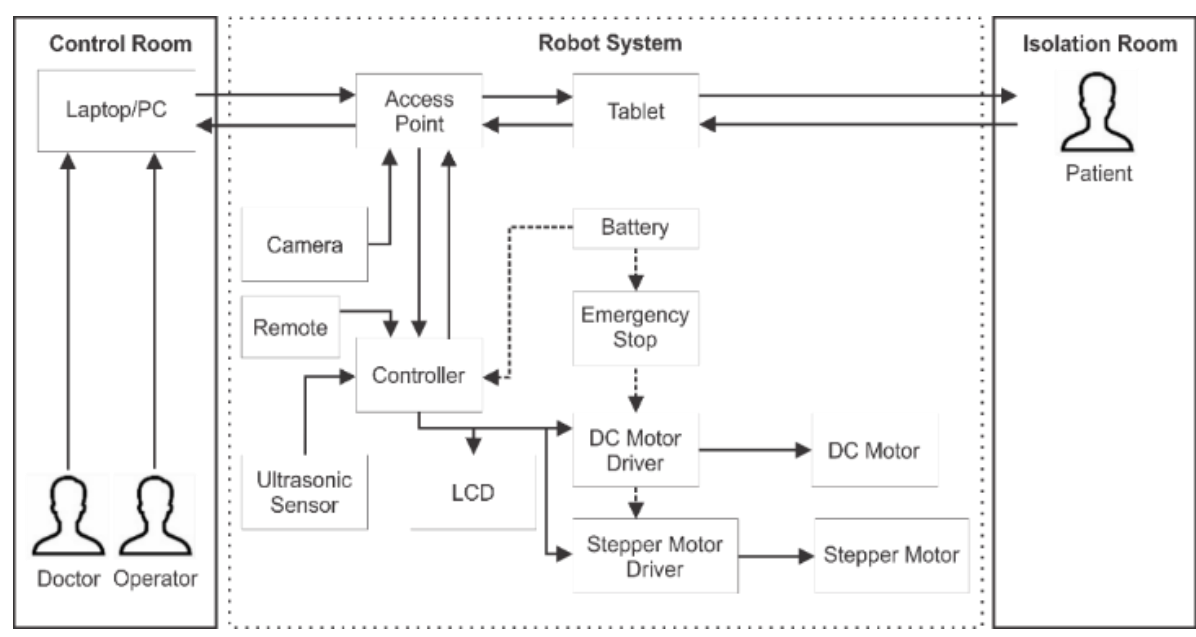

Figure 2. The robot system block diagram 
The microcontroller used in this study were 2 Arduino Uno with ATMega 328p as main controller. The use of these 2 microcontrollers is for receiving data from desktop applications on a laptop/PC to control the robot, and also sending sensor and camera data to desktop applications. The robot in this study is also equipped with a motor driver using the BTN 8982 IC with a constant current capacity of 30A to drive a reduced $24 \mathrm{v} 300 \mathrm{rpm}$ DC motor with 1:3 gears. Then, to install all these components, stainless steel SUS 304L is used as a box panel and frame and robot tray. The detail of medical robot, controller board and overall design of the hardware and robot mechanics can be seen in Figure 3.
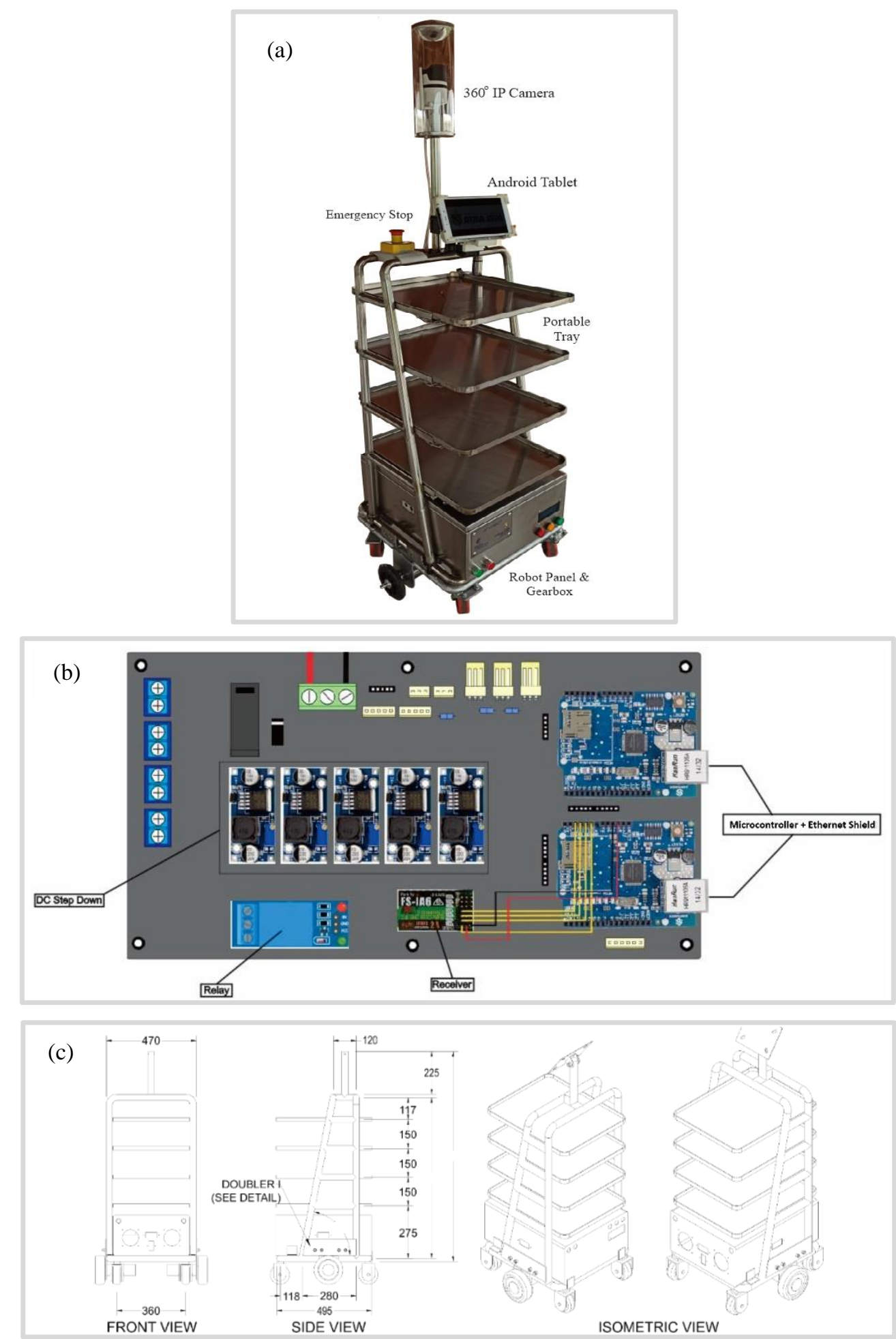

Figure 3. (a) Medical robot, (b) Controller board, (c) Mechanical robot design 


\subsection{Software}

The software designed in this study includes desktop applications for laptops/PCs as well as robot operating system (OS). Desktop applications for laptops/PCs were developed using the basic programming language using visual basic IDE 6. As for microcontroller programming, the Arduino IDE v1.8.12 was used in this study to support the development of robot OS with C-like programming language because of its simple use [30]-[32] compared to using raspberry pi [33]. In addition, a server to support internal video conferencing was developed using Jitsi Meet. Jitsi Meet is an open source platform for video conferencing from www.jitsi.org [34], [35].

\subsection{Programming}

There are 3 programming carried out in this study including coding development for microcontrollers as receivers and processing control data from desktop applications to robots, coding development for microcontrollers as processing and sending sensor data from robots to desktop applications, and developing coding for desktop applications itself. Broadly speaking, the robot's logic can be interpreted as shown in the flowchart Figure 4.

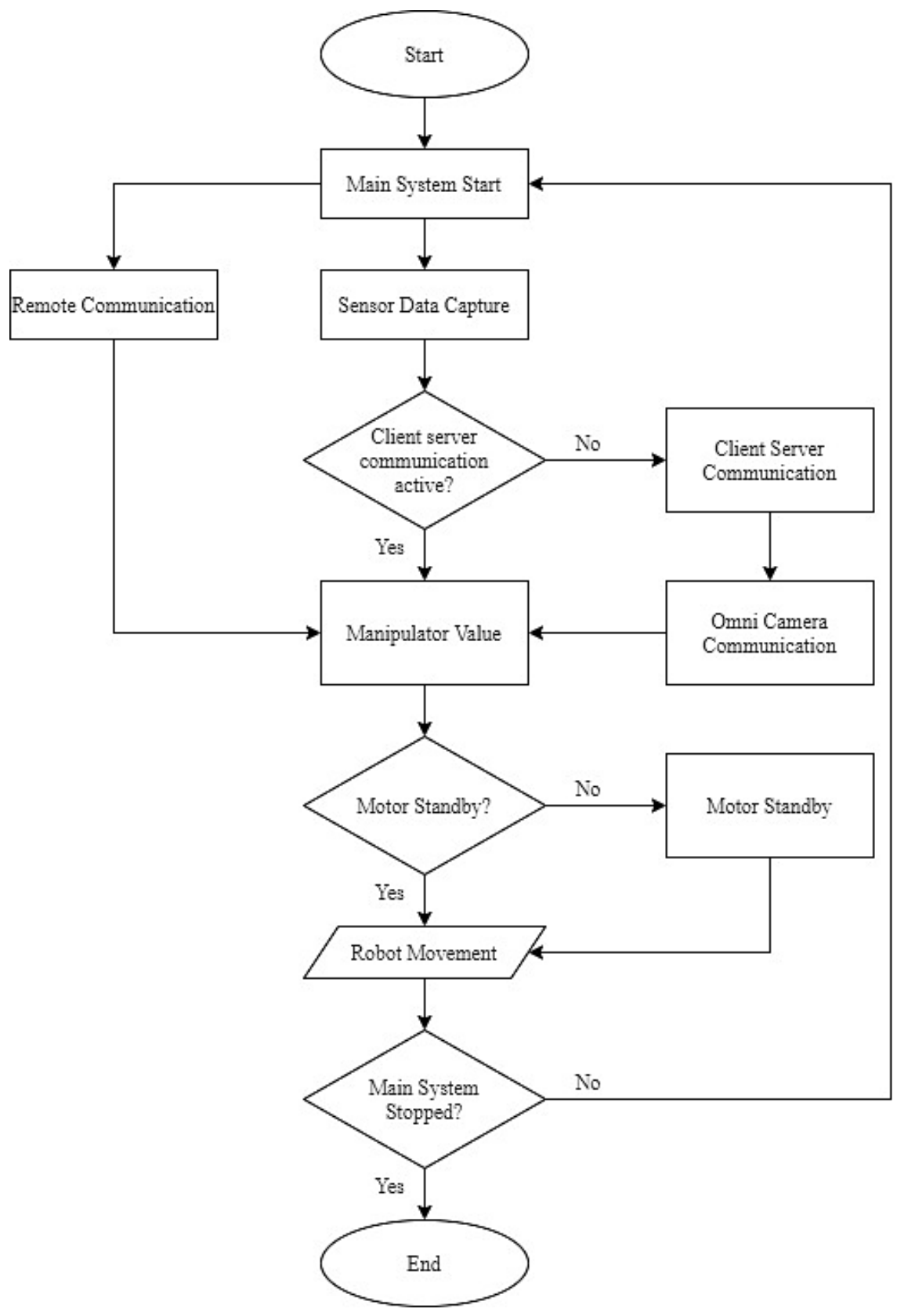

Figure 4. System flowchart 


\section{RESULTS AND ANALYSIS}

\subsection{Robot system testing result}

There are 4 technical testing criteria carried out in this study, including speed test with and without load, distance measurement test on 3 sides of the robot (front, right, left), control distance testing, and motor performance testing. The following are the results of technical testing.

\subsection{Robot speed test with and without load}

Robot running a test with load and without load is carried out to determine the speed performance of the robot against the load carried. $12.59 \mathrm{~kg}$ of the metal load has been used to test the robot. robot speed test results data with and without load can be seen in Table 2. Based on the data obtained from the robot speed test with load and no load, it can be concluded that there is a slowing speed that is not too significant, namely at $0.43 \mathrm{~s}$ with an average percentage of slowdown of $8.96 \%$.

Table 2. Robot speed test with load and no load

\begin{tabular}{lccc}
\hline \multirow{2}{*}{ Testing (within 5m) } & \multicolumn{3}{c}{ Testing time (s) } \\
& 1 & 2 & 3 \\
\hline No Load & 8.17 & 8.05 & 8.05 \\
With Load $(12.59 \mathrm{~kg})$ & 8.57 & 8.49 & 8.50 \\
\hline
\end{tabular}

\subsection{Distance measurement test on 3 side of robot (rear, right, left)}

Robot distance measurement test is carried out to determine the accuracy of the measurement distance from the distance sensor to the actual distance. The data from the distance measurement test results on the 3 sides of the robot (front, right, left) can be seen in Table 3. Based on the distance measurement test data on the 3 sides of the robot (front, right, left) it can be concluded that the accuracy rate is close to perfect with an accuracy percentage of $99.62 \%$.

Table 3. Distance measurement test on 3 side of robot (rear, right, left)

\begin{tabular}{cccc}
\hline Distance Measurement & Right Sensor & Left Sensor & Rear Sensor \\
\hline Monitor Display Average & 518 & 520 & 520 \\
Actual Average Distance & 516 & 518 & 518 \\
\hline
\end{tabular}

\subsection{Robot control distance test}

Robot control distance testing is carried out to see the performance of the robot controlled remotely. Robot control distance test was carried out with 2 experiments. In the first experiment the robot runs well at a distance between rooms as far as $35.2 \mathrm{~m}$. The second experiment is also went well and remained connected via the access point at a total travel distance of $56.8 \mathrm{~m}$. The first and second experimental schemes can be seen in Figure 5.

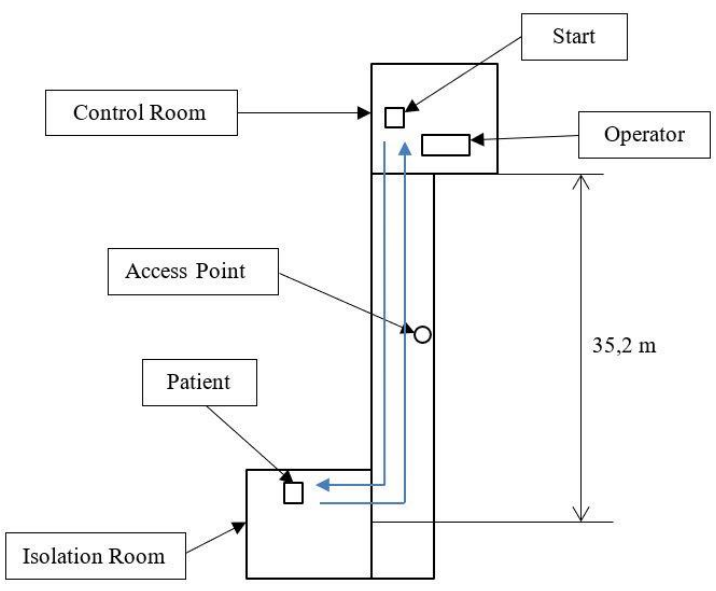

(a)

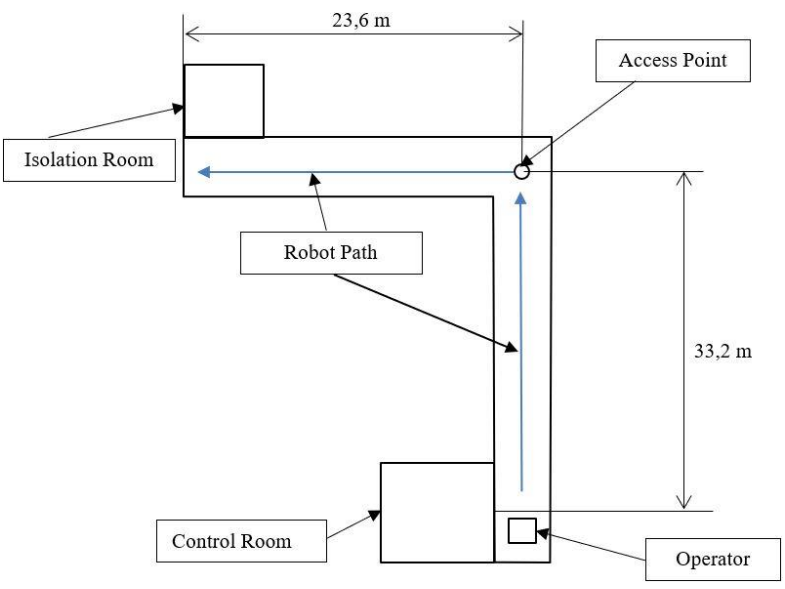

(b)

Figure 5. Robot controlling distance test experiment scheme: (a) first experiment and (b) second experiment 


\subsection{Motor performance test}

Motor performance testing is carried out to see the significance of the increase in motor temperature before and after work. In this study the Fluke Tis40 Thermal Imager was used to measure the temperature of the right motor and left motor. Test data can be seen in Figure 6. Based on the motor test data before and after working, the motor temperature did not increase significantly from 24.9 to $32.9^{\circ} \mathrm{C}$. It can be represented that the increase in temperature is only $32.13 \%$.

\subsection{Feasibility test result}

The feasibility test in this study is based on the usability aspect assessed by users based on the FGD results. Responses from usability aspects were collected by means of a questionnaire with several points representing the sub-aspects of operability, understandability, attractivenes, and learnability. Feasibility test data can be seen in Figure 7. By data shown in Figure 7, the total mean of the feasibility score is 91.46 out of 100 points. In other words, from the data in the table, the percentage of feasibility can be represented using the equation previously described (2).

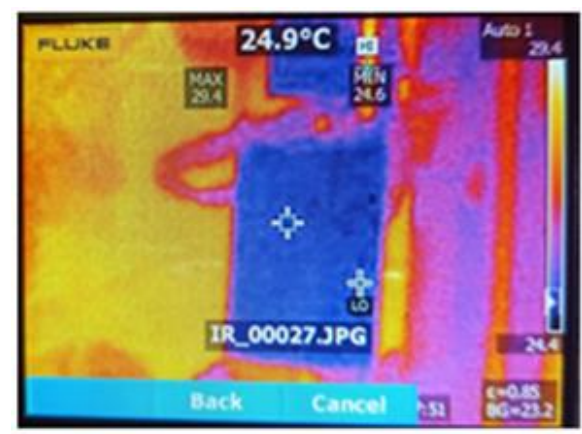

(a)

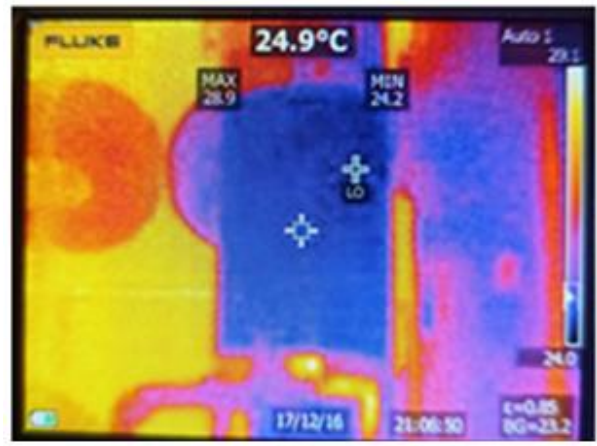

(c)

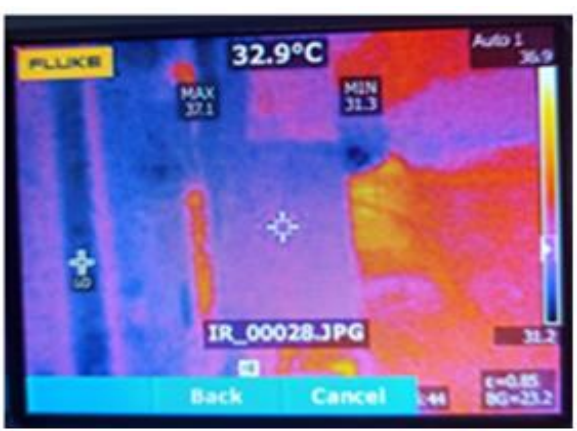

(b)

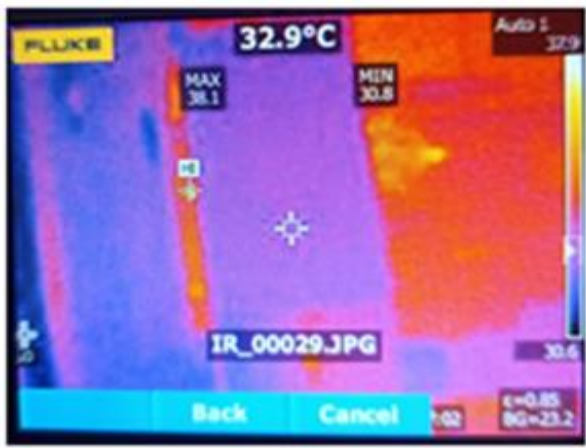

(d)

Figure 6. Motor temperature testing: (a) left motor before working, (b) left motor after working, (c) right motor before working and (d) right motor after working

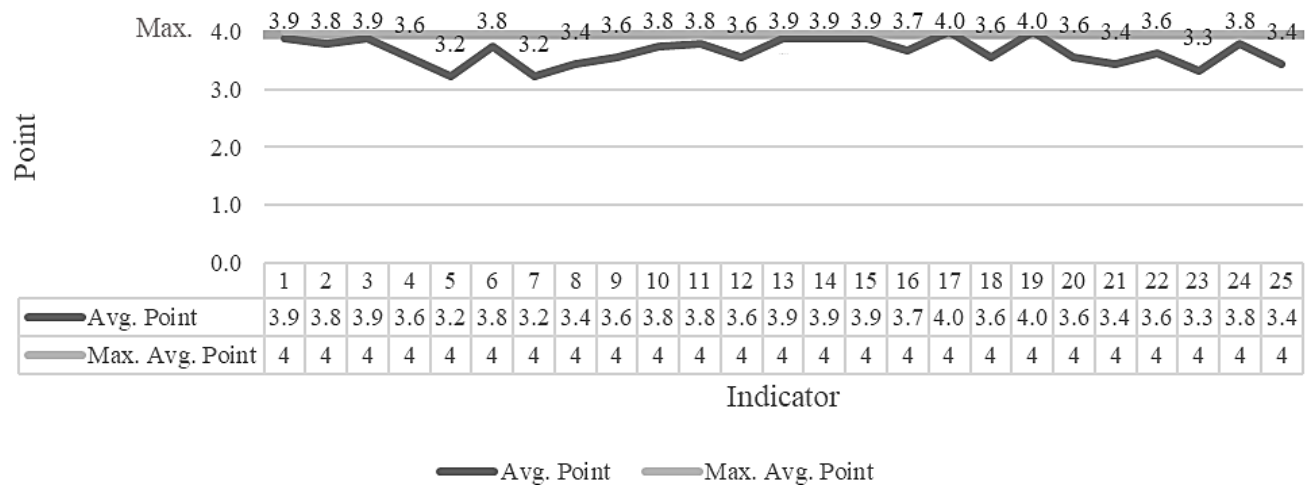

Figure 7. Feasibility test result 


$$
\begin{aligned}
& \text { Feasibility }=\frac{\text { Total Avg.Point }}{\text { Total Max.Avg.Point }} \times 100 \% \\
& \text { Feasibility }=\frac{91.46}{100} \times 100 \% \\
& \text { Feasibility }=91.46 \%
\end{aligned}
$$

Based on the results of the feasibility test, it can be represented that from each assessment item after being converted into qualitative data, all aspects of the development study of healthcare mobile robot for helping medical personnel in dealing with COVID-19 patients are included in the very feasible category to be used with a percentage of eligibility, amounted to $91.46 \%$.

\section{CONCLUSION}

Overall, the testing of healthcare mobile robots for helping medical personnel in dealing with COVID-19 patients is good and very feasible. This can be concluded from the good technical and nontechnical testing. From technical testing related to the movement of the robot with a load of $12.59 \mathrm{~kg}$, it only experienced a slow speed which was not too significant, namely at $0.43 \mathrm{~s}$ with an average percentage of $8.96 \%$ deceleration. In addition, the accuracy rate of the proximity sensor testing is close to perfect with an accuracy percentage of $99.62 \%$. The robot control distance was monitored and the test was running well. Also, the increase in motor temperature which is not too big is supported by the measurement results of the increase in motor temperature of only $32.13 \%$. From non-technical testing, based on the test results from the feasibility test of all respondents with 25 indicators, the results of the development of this study reached an eligibility level of $91.46 \%$. In other words, healthcare mobile robots developed for helping medical personnel in dealing with COVID-19 patients very feasible to be applied in the hospital.

\section{ACKNOWLEDGEMENTS}

The authors thank the Faculty of Engineering at Universitas Katolik Indonesia Atma Jaya, Atma Jaya Hospital, and Faculty of Engineering Alumnae (AKUTEKNIK) that has fully supported our research.

\section{REFERENCES}

[1] World Health Organization. Report of the WHO-China Joint Mission on Coronavirus Disease 2019 (COVID-19), WHO: Geneva, Switzerland, 2020.

[2] Z. H. Khan, A. Khalidb, and J. Iqbal, "Towards realizing robotic potential in future intelligent food manufacturing systems," Innov. Food Sci. Emerg. Tech. vol. 48, pp. 11-24, 2018, doi:10.1016/j.ifset.2018.05.011.

[3] J. Iqbal, Z. H. Khan, and A. Khalid, "Prospects of robotics in food industry," Food Sci. Technol. vol. 37, pp. 159165, 2017, doi:10.1590/1678-457x.14616.

[4] J. Iqbal, M. R. UI Islam, S. Z. Abbas, A. A. Khan and S. A. Ajwad, "Automating industrial tasks through mechatronic systems-A review of robotics in industrial perspective,” Tehnički vjesnik vol. 23, no. 3, pp. 917-924, 2016, doi:10.17559/TV-20140724220401.

[5] A. M. Tahir, J. Iqbal, T. Aized, "Human machine interface: robotizing the instinctive living," International Robotics \& Automation Journal. vol. 4, pp. 308-314, 2018, doi:10.15406/iratj.2018.04.00142.

[6] F. Capezio, et al, "Mobile Robots in Hospital Environments: an Installation Case Study," ECMR. pp. 1-7. 2011. doi: http://www.aass.oru.se/Agora/ECMR2011/proceedings/papers/ECMR2011_0038

[7] M. Zukowski, et al., "Humanoid medical assistant and companion robot for patients," AIP Conference Proceedings, 2029, 020086. 2018, doi: 10.1063/1.5066548.

[8] N. Chivarov, D. Chikurtev, K. Yovchev, and S. Shivarov, "Cost-Oriented Mobile Robot Assistant for disabled Care," IFAC-PapersOnLine. vol. 48, no. 24, pp. 128-133, 2015, doi: 10.1016/j.ifacol.2015.12.069.

[9] M. Shishehgar, D. Kerr, and J. Blake, "A systematic review of research into how robotic technology can help Elder people," Smart Health. pp. 1-18, 2018, doi:10.1016/J.SMHL.2018.03.002.

[10] R. Bogue, "Europe leads the way in assistive robots for the elderly," Industrial Robot: the international journal of robotics research and application, vol. 44 no. 3, pp. 253-258, 2017, doi: 10.1108/IR-02-2017-0041.

[11] A. A. Allaban, M. Wang, and T. Padır, "A Systematic Review of Robotics Research in Support of In-Home Care for Older Adults," Information, vol. 11, no. 75, 2020, doi: 10.3390/info11020075.

[12] A. H. Basori, "End-effector wheeled robotic arm gaming prototype for upper limb coordination control in homebased therapy," TELKOMNIKA Telecommunication Computing Electronics and Control, vol. 18 no. 4, pp. 2080 2086, 2020, doi: 10.12928/telkomnika.v18i4.3775.

[13] M. Ilyas, A. Khaqan, J. Iqbal, and R. A. Riaz, "Regulation of hypnosis in Propofol anesthesia administration based on non-linear control strategy," Braz J Anesthesiol, vol. 67, no. 2, pp. 122-130, 2017, doi: 10.1016/j.bjane.2015.08.011. 
[14] M. Ilyas, J. Iqbal, S. Ahmad, A. Arshad, W. A. Imtiaz, and R. A. Riaz, "Hypnosis regulation in propofol anesthesia employing super-twisting sliding mode control to compensate variability dynamics," IET Syst. Biol., Oct. 2019, doi:10.1049/iet-syb.2018.5080.

[15] W. Alam, N. Ali, S. Ahmad, and J. Iqbal, "Super twisting control algorithm for blood glucose regulation in type 1 diabetes patients," 15th International Bhurban Conference on Applied Sciences and Technology (IBCAST), Islamabad, 2018, pp. 298-303, doi: 10.1109/IBCAST.2018.8312239.

[16] J. Iqbalab, H. Khana, N. G. Tsagarakisa, and D. G. Caldwell, "A novel exoskeleton robotic system for hand rehabilitation-Conceptualization to prototyping," Biocybernetics and Biomedical Engineering, vol. 34, no. 2, pp. 79-89. 2014, doi: 10.1016/j.bbe.2014.01.003.

[17] J. Iqbal, N. G. Tsagarakis, D. G. Caldwell, "Human hand compatible underactuated exoskeleton robotic system," Electronics Letters, vol. 50, no. 7, pp. 494. 2014, doi: 10.1049/el.2014.0508.

[18] J. Iqbal, N. G. Tsagarakis, D. G. Caldwell, "A helping hand: A lightweight, flexible, under-actuated exoskeleton hand with a wide range of potential applications from medicine to entertainment," Electronics Letters, 2015, doi:10.1049/el.2015.1751.

[19] J. Iqbal, N. G. Tsagarakis, D. G. Caldwell, "Four-fingered lightweight exoskeleton robotic device accommodating different hand sizes," Electronics Letters, vol. 51, no. 12, pp. 888, 2015, doi: 10.1049/el.2015.0850.

[20] K. Naveed, J. Iqbal, and H. U. Rahman, "Brain controlled human robot interface," IEEE International Conference on Robotics and Artificial Intelligence/Islamabad, Pakistan, 2012, pp. 55-60, doi: 10.1109/ICRAI.2012.6413410.

[21] L. Shi, Y. Yu, N. Xiao, and D. Gan, "Biologically Inspired and Rehabilitation Robotics," Applied Bionics and Biomechanics, vol. 2019, Article ID 2428707, 2 pages, 2019, doi: 10.1155/2019/2428707.

[22] A. C. Lo, L. Richards, P. D. Guarino, and J. Haselkorn, "Robot-Assisted Therapy for Long-Term Upper-Limb Impairment after Stroke," The New England Journal of Medicine, vol. 362, pp. 1772-1783, 2010, doi: 10.1056/nejmoa0911341.

[23] P. Zhao, B. Zi, A. Purwar, and N. An, "Editorial: Special issue on rehabilitation robots, devices and methodologies," J. Eng. Sci. Med. Diagn. Ther. vol. 3, no. 1, 2020, doi: 10.1115/1.4046325.

[24] C. E. Zant, N. Klement, B. Bettayeb, M'H. Sahnoun, and V. Havard, "UV-Robot supervision system design and development," 25ème colloque des Sciences de la conception et de l'innovation, Budapest, Hungary, hal-02053320, 2018 doi: https://hal.archives-ouvertes.fr/hal-02053320

[25] S. Balasubramanian, "The era of robotics: Dexterity for surgery and medical care: Narrative review," International Surgery Journal, vol. 7 no. 4, pp. 1317-1323, 2020, doi:10.18203/2349-2902.isj20201057.

[26] A. A. Syed, A. M. Soomro, A. N. Khizar, X.-G. Duan, H. Qiang, F. Manzoor, "Tele-Robotic Assisted Dental Implant Surgery with virtual Force Feedback," TELKOMNIKA Telecommunication Computing Electronics and Control, vol. 12 no.1, pp. 450-458. 2014, doi: 10.11591/telkomnika.v12i1.3124.

[27] L. Bai, J. Yang, X. Chen, Y. Sun, and X. Li, "Medical Robotics in Bone Fracture Reduction Surgery: A Review," Sensors (Basel, Switzerland), vol. 19, no. 3593, pp. 1-19, 2019, doi: 10.3390/s19163593.

[28] R. S. Pressman, "Software Engineering: A Practitioner's Approach,” New York: McGraw-Hill, 2001.

[29] R. Likert, "A Technique for the Measurement of Attitudes," Archives of Psychology, vol. 140, pp. 1-55, 1932.

[30] A. B. D. Nandiyanto, R. Zaen, R. Oktiani, A. G. Abdullah, and L. S. Riza, "A simple, rapid analysis, portable, lowcost, and Arduino-based spectrophotometer with white LED as a light source for analyzing solution concentration," TELKOMNIKA Telecommunication Computing Electronics and Control, vol. 6 no. 2, pp. 580, 2018, doi: 10.12928/telkomnika.v16i2.7159.

[31] H. Muhammad Asraf, K. A. Nur Dalila, A. W. Muhammad Hakim and R. H. Muhammad Faizzuan Hon, "Development of Experimental Simulator via Arduino-based PID Temperature Control System using LabVIEW," J. Telecommun. Electron. Comput. Eng. vol. 9, pp. 53-57. 2017. doi: https://core.ac.uk/reader/229275410

[32] Jidin A. Z, Yusof N. M, Sutikno T, "Arduino Based Paperless Queue Management System," TELKOMNIKA Telecommunication Computing. Electronics.and Control, vol. 14 no. 3, pp. 839-846. 2016, doi: 10.12928/telkomnika.v14i3.3114.

[33] Budiyanta, N. E., Sereati C. O., Lukas, "PD controller computer vision and robotics integration based for student's programming comprehension improvement," TELKOMNIKA Telecommunication Computing. Electronics.and Control, vol. 18 no. 2, pp. 899-906. 2020, doi:10.12928/telkomnika.v18i2.14881.

[34] Asfar, A. M. I. T, and Asfar, A. M. I. A., "How To Using Online Meeting On Jitsi Meet Aplication," 2020, doi: 10.13140/RG.2.2.28536.80644.

[35] Grozev B, L. Marinov, V. Singh, and E. Inov, "Last N: relevance-based selectivity for forwarding video in multimedia conferences," In Proceedings of the 25th ACM Workshop on Network and Operating Systems Support for Digital Audio and Video (NOSSDAV '15), Association for Computing Machinery, New York, NY, USA, 2015, pp. 19-24, doi: 10.1145/2736084.2736094. 2015. 


\section{BIOGRAPHIES OF AUTHORS}
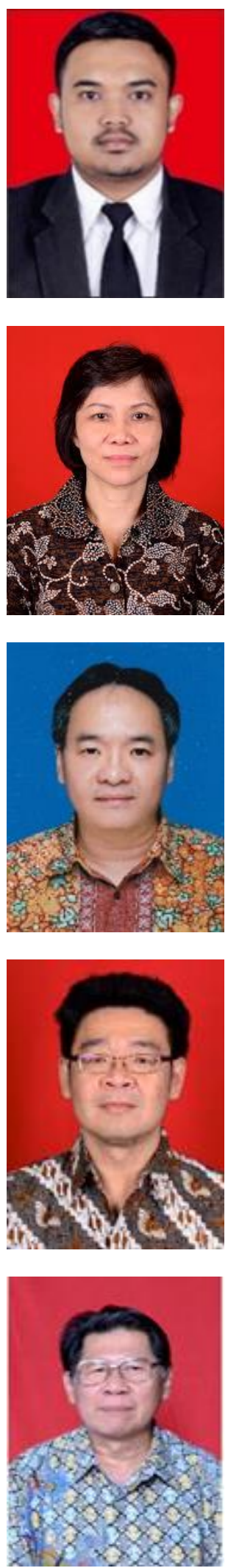

Nova Eka Budiyanta got his Bachelor Degree in Mechatronics Engineering Education from Universitas Negeri Yogyakarta, then pursuing his Master Degree in Electrical Engineering Education from Universitas Negeri Yogyakarta and Electrical Engineering Master Program from Universitas Katolik Indonesia Atma Jaya. He has experience in hardware-software programming. Now acting as lecturer and the Head of Robotics and Intelligence Computing Laboratory of Electrical Engineer Department, Universitas Katolik Indonesia Atma Jaya with concern in image processing, robotics, and machine learning research field.

Linda Wijayanti got her Bachelor Degree in Electrical Engineering form Universitas Katolik Indonesia Atma Jaya, then pursuing her Master Degree in Electrical Engineering from Institut Teknologi Bandung. She has experience in control system. Now acting as a lecturer in Electrical Engineering Department, Universitas Katolik Indonesia Atma Jaya with concern in control system research field.

Widodo Widjaja Basuki got his Bachelor Degree in Mechanical Engineering form Universitas Katolik Indonesia Atma Jaya, then pursuing his Master Degree and Doctoral Degree in Mechanical Engineering from Universitat Karlsruhe TH. He has experience in Material and Energy. Now acting as a lecturer in Mechanical Engineering Department and Vice Dean for Faculty of Engineering, Universitas Katolik Indonesia Atma Jaya with concern in Material and Energy research field.

Harlianto Tanudjaja got his Bachelor Degree in Electrical Engineering form Universitas Trisakti, then pursuing his Master Degree in Electrical Engineering from Universitas Indonesia. He has experience in Sensor and Instrumentation. Now acting as a lecturer and Head of Study Program for Information System Department, Universitas Katolik Indonesia Atma Jaya with concern in Instrumentation research field.

V. Budi Kartadinata got his Bachelor Degree in Electrical Engineering form Universitas Trisakti, then pursuing his Master Degree in Electrical Engineering from Universitas Indonesia. He has experience in Power Electronics. Now acting as a lecturer in Electrical Engineering Department, Universitas Katolik Indonesia Atma Jaya with concern in Industrial Control and Power Electronics research field. 